\title{
SISTEM INFORMASI PENERBITAN AKTA CERAI DI PENGADILAN AGAMA LUMAJANG
}

\author{
Muhamad Ightana Hakim Ilmi \\ Program Studi Teknik Informatika S1, Fakultas Teknologi Industri \\ Institut Teknologi Nasional Malang, Jalan Raya Karanglo km 2 Malang, Indonesia \\ 1518078@scholar.itn.ac.id
}

\begin{abstract}
ABSTRAK
Akta cerai merupakan suatu surat bukti outentik tentang putusnya suatu ikatan perkawinan setelah adanya putusan pengadilan dan akta cerai bisa diterbitkan jika gugatan dikabulkan oleh majelis hakim dan perkara tersebut telah berkekuatan hukum tetap (inkracht). Syarat mengambil Akta Cerai dengan sitim penelusuran perkara (SIPP) : 1. Menyerahkan nomor perkara yang dimaksud, 2. Memperlihatkan KTP Asli dan menyerahkan fotokopinya, 3. Membayar Penerimaan Negara Bukan Pajak (PNBP).

Adapun Sistem penelusuran perkara disetiap pengadilan agama yang telah diprogramkan oleh Mahkamah Agung yang dikenal dengan Sistem Informasi Penelusuran Perkara (SIPP), merupakan suatu sistem dasar penyelesaian perkara berbasis Web. Namun, SIPP ini masih terdapat kekurangan sehingga diperlukan penyempurnaan dalam upaya mendukung kesempurnaan SIPP dalam aplikasinya dalam rangka melaksanakan pelayanan terpadu satu pintu ( PTSP ), yang salah satunya adalah sistem untuk pengambilan akta cerai. Sitem lama, pihak yang mengambil akta cerai akan menadatangani buku kendali pengambilan akta cerai, hal tersebut sebagai bukti bahwa pihak telah mengambil akta cerai pada hari dan tanggal yang tertera pada buku kendali tersebut.Namun sering terjadi akta cerai diambil bukan oleh pihak yang bukan bersangkutan (bercerai) dengan cara pemalsuan dokumen. Sehingga sering terjadi perselisihan antara pihak pihak yang bercerai dengan petugas pengadilan.

Oleh karena itu Pengadilan Agama Lumajang memerlukan sebuah sistem informasi sebagai pendukung SIPP yang dapat memberikan bukti secara pasti mengenai pihak yang telah mengambil akta cerai. Aplikasi ini diharapkan dapat meminimalisir adanya konflik dari pihak-pihak yang berperkara, dan aplikasi berbasis website ini dalam rangka memberikan pelayanan terpadu satu pintu yang di singkat dengan PTSP .

Terbentuknya aplikasi PTSP ini bermula dari adanya petugas informasi dan pengambilan Akta cerai secara manual, hal tersebut menyebabkan terjadinya permasalahn diantaranya adanya complain dari para pencari keadilan tentang sudah dan belumnya mengambil aka cerai. Untuk menjawan dan memperoleh jalan keluar dari permasalahan tersebut maka diciptakan aplikasi yang berbasis web, sehingga diharapkan tidak terjadi lagi adanya complain dari para pihak pencari keadilan.

Aplikasi PTSP ini dibuat guna memberikan pelayanan prima oleh pencari keadilan, yang mana aplikasi terdiri dari pelaayanan informasi dan pengambilan akta cerai yang terintergrasi dengan aplikasi induk di pengadilan agama lumajang yaitu SIPP. Untuk pelayanan pengambilan akta cerai juga terintergrasi dengan aplikasi induk SIPP agar terkendali dengan baik pengambilan akta cerai dan akta cerai yang belum di ambil oleh para pihak, sehingga bisa diminimalisir kesalahan pengambilan akta cerai.
\end{abstract}

Kata kunci : Meminimalisir Kesalahan Pengambilan Akta Cerai.

\section{PENDAHULUAN}

Pengadilan Agama Lumajang, pada mulanya timbul dari kesadaran masyarakat Islam akan syariat agamanya. Pengadilan ini sebenarnya salah satu dari lembaga tatanan Umat Islam (lembaga Non Formil) yang dibiarkan, tapi diakui adanya oleh penguasa kolonial Belanda. Sampai sekarangpun Pengadilan Agama Luamajang tetap berdiri kokoh, sebagai pelaksana kekuasaan kehakiman yang ada di Negara Republik Indonesia.

Tugas dan fungsi Pengadilan Agama Lumajang selaku salah satu kekuasaan Kehakiman di lingkungan Peradilan Agama, diatur dalam
Undang-Undang Nomor 50 Tahun 2006 tentang Perubahan Kedua Atas Undang-Undang Nomor 7 Tahun 1989 tentang Peradilan Agama.

Sebagai Pengadilan ditingkat pertama Pengadilan AgamaLumajangbertugas dan berwenang menerima, memeriksa, memutus dan menyelesaikan perkara-perkara di tingkat pertama antara orang-orang yang beragama Islam di bidang perkawinan, waris, wasiat, hibah, wakaf, zakat, infaq, shadaqah dan ekonomi syari'ah sebagaimana diatur dalam UndangUndang Nomor 3 Tahun 2006 tentang perubahan atas Undang-Undang Nomor 7 Tahun 1989 tentang Peradilan Agama yang sekarang telah diubah dengan 
Undang-Undang Nomor 50 Tahun 2009 Tentang Perubahan Kedua atas undang-Undang Nomor 7 Tahun 1989 Tentang Peradilan Agama.

Pengadilan Agama dalam melaksanakan tugas sehari - harinya, telah diciptakan suatu Aplikasi SIPP ( Sistim Informasi Penelusuran Perkara ) yang diciptakan oleh Mahkamah Agung, merupakan suatu sistem dasar penyelesaian perkara melalui tehnologi informasi yang berbasis Web. Namun demikian SIPP yang berbasis Web masih terdapat kekuarangan sehingga diperlukan penyempurnaan dalam upaya mendukung kesempurnaan SIPP dalam aplikasinya, karena masih terdapatnya item - item azas berperkara sederhana, cepat, biaya ringan yang belum terakses dalam aplikasi SIPP, karena sifat dari aplikasi SIPP masih sangat global. Dan sifat Globalnya SIPP , masing masing item harus dilakukan sesuai dengan tahapan berperkara, dan tidak bisa dilakukan secara loncat - loncat yang tanpa melaui tahapan yang sesuai dengan praktek hukum acara.

Akta cerai merupakan suatu surat bukti outentik tentang putusnya suatu ikatan perkawinan setelah adanya putusan pengadilan, begitu juga apabila Akta Perkawinan dikeluarkan oleh Kantor Catatan Sipil, maka seseorang yang akan mengakhiri ikatan perkawinannya (cerai) juga harus diajukan melalui Pengadilan, Penerbitan Akta Cerai dilakukan setelah putusan berkekuatan hukum tetap. Jadi Akta cerai merupakan bukti outentik atas sahnya perceraian yang dilakukan oleh seorang suami dan seorang istri, dan dengan akta cerai itu pula sebagai dasar dan Legalitas putusnya perkawinan, akta cerai pula yang digunakan sebagai dasar untuk melakukan perubahan status, sebagai janda cerai atau duda cerai.

Akta cerai bisa diterbitkan jika gugatan dikabulkan oleh majelis hakim dan perkara tersebut telah berkekuatan hukum tetap (inkracht). Perkara dikatakan telah berkekuatan hukum tetap jika dalam waktu 14 hari sejak putusan dibacakan (dalam hal para pihak hadir), salah satu atau para pihak tidak mengajukan upaya hukum. Dalam hal pihak tidak hadir, maka perkara baru berkekuatan hokum tetap) inkracht terhitung 14 hari sejak pemberitahuan isi putusan disampaikan kepada pihak yang tidak hadir dan yang bersangkutan tidak melakukan upaya hukum (putusan kontradiktoir) atau verzet (putusan verstek).

Syarat mengambil Akta Cerai:

1. Menyerahkan nomor perkara yang dimaksud.

2. Memperlihatkan KTP Asli dan menyerahkan fotokopinya.

3. Membayar Penerimaan Negara Bukan Pajak (PNBP).

Sistem disetiap pengadilan agama saat ini dari Mahkamah Agung adalah Sistem Informasi Penelusuran Perkara (SIPP), yang merupakan suatu sistem dasar penyelesaian perkara berbasis Web. Namun, SIPP ini masih terdapat kekurangan sehingga diperlukan penyempurnaan dalam upaya mendukung kesempurnaan SIPP dalam aplikasinya. Salah satunya adalah sistem untuk pengambilan akta cerai.Saat ini pihak yang mengambil akta cerai akan menadatangani buku kendali pengambilan akta cerai, hal tersebut sebagai bukti bahwa pihak telah mengambil akta cerai pada hari dan tanggal yang tertera pada buku kendali tersebut.Namun sering terjadi akta cerai diambil bukan oleh pihak yang bukan bersangkutan (bercerai) dengan cara pemalsuan dokumen. Sehingga sering terjadi perselisihan antara pihak pihak yang bercerai dengan petugas pengadilan.

\section{TINJAUAN PUSTAKA}

\subsection{Pengertian Sistem Informasi}

Sistem informasi yaitu suatu sistem yang menyediakan informasi untuk manajemen dalam mengambil keputusan dan juga untuk menjalankan operasional perusahaan, di mana sistem tersebut merupakan kombinasi dari orangorang, teknologi informasi dan prosedurprosedur yang tergorganisasi. Biasanya suatu perusahan atau badan usaha menyediakan semacam informasi yang berguna bagi manajemen. Sebagai contoh: Perusahaan toko buku mempunyai sistem informasi yang menyediakan informasi penjualan buku-buku setiap harinya, serta stock buku-buku yang tersedia, dengan informasi tersebut, seorang manajer bisa membuat kebutusan, stock buku apa yang harus segera mereka sediakan untuk toko buku mereka, manajer juga bisa tahu buku apa yang paling laris dibeli konsumen, sehingga mereka bisa memutuskan buku tersebut jumlah stocknya lebih banyak dari buku lainnya.

\subsubsection{Pengertian sistem informasi menurut John F. Nash}

Sistem Informasi adalah kombinasi dari manusia, fasilitas atau alat teknologi, media, prosedur dan pengendalian yang bermaksud menata jaringan komunikasi yang penting, proses atas transaksi-transaksi tertentu dan rutin, membantu manajemen dan pemakai intern dan ekstern dan menyediakan dasar pengambilan keputusan yang tepat.

\subsubsection{Pengertian sistem informasi menurut Henry Lucas}

Sistem Informasi adalah suatu kegiatan dariprosedurprosedur yang diorganisasikan, bilamana dieksekusi akan menyediakan informasi untuk mendukung pengambilan keputusan dan pengendalian di dalam.

\subsection{Pengertian Web}

Web merupakan jaringan komputer yang terdiri dari sekumpulan situs internet yang 
menampilkan teks, grafik, gambar maupun suara melalui protokol transfer hypertext.

Pemrograman web itu merupakan salah satu cara membuat web dengan implementasi kodekode bahasa pemrograman yang dapat berjalan di server. Bahasa pemrograman yang mendukung pemrograman web ini antara lain PHP, JSP, ASP dan lain-lain. Pada pemrograman web terdapat 2 sisi programming. Yang pertama itu Client side programming, client side programming itu proses dilakukan pada sisi client (browser), script programnya dapat dilihat hanya dengan menggunakan view source. Script tergantung pada browser, bila browser tidak mendukung script, maka hasil tidak akan terlihat. Trus yang kedua itu Server side programming yaitu proses dilakukan pada sisi server, tidak tergantung pada browser, script programnya tidak dapat terlihat sehingga lebih aman dan dapat melakukan konektifitas dengan database, dapat juga memanipulasi.

\subsection{Pengertian Pengadilan Agama}

Pengadilan Agama Lumajang, pada mulanya timbul dari kesadaran masyarakat Islam akan syariat agamanya. Pengadilan ini sebenarnya salah satu dari lembaga tatanan Umat Islam (lembaga Non Formil) yang dibiarkan, tapi diakui adanya oleh penguasa kolonial Belanda. Sampai sekarangpun Pengadilan Agama Luamajang tetap berdiri kokoh, sebagai pelaksana kekuasaan kehakiman yang ada di Negara Republik Indonesia.

Pengadilan Agama Lumajang merupakan lembaga kekuasaan kehakiman yang bertugas mengadili perkara tingkat pertama dan berkedudukan di Kabupaten Lumajang. Sebagai kawal depan (voor-post) Mahkamah Agung RI, Pengadilan Agama Lumajang membawahi 21 Kecamatan 205 Desa dengan luas wilayah yurisdiksi 1386 dengan diapit oleh 3 kabupaten, dan Samudra Indonesia, yakni :

Sebelah Utara $=$ Kabupaten Probolinggo

Sebelah Timur $=$ Kabupaten Jember

Sebelah Selatan $=$ Samudra Indonesia

Sebelah Barat $=$ Kabupaten Malang

Tugas dan fungsi Pengadilan Agama Lumajang selaku salah satu kekuasaan Kehakiman di lingkungan Peradilan Agama, diatur dalam Undang-Undang Nomor 50 Tahun 2006 tentang Perubahan Kedua Atas Undang-Undang Nomor 7 Tahun 1989 tentang Peradilan Agama.

Sebagai Pengadilan ditingkat pertama Pengadilan Agama Lumajang bertugas dan berwenang menerima, memeriksa, memutus dan menyelesaikan perkara-perkara di tingkat pertama antara orang-orang yang beragama Islam di bidang perkawinan, waris, wasiat, hibah, wakaf, zakat, infaq, shadaqah dan ekonomi syari'ah sebagaimana diatur dalam UndangUndang Nomor 3 Tahun 2006 tentang perubahan atas Undang-Undang Nomor 7 Tahun 1989 tentang Peradilan Agama yang sekarang telah diubah dengan Undang-Undang Nomor 50 Tahun 2009 Tentang Perubahan Kedua atas undang-Undang Nomor 7 Tahun 1989 Tentang Peradilan Agama.

Pengadilan Agama dalam melaksanakan tugas sehari - harinya, telah diciptakan suatu Aplikasi SIPP ( Sistim Informasi Penelusuran Perkara ) yang diciptakan oleh Mahkamah Agung, merupakan suatu sistem dasar penyelesaian perkara melalui tehnologi informasi yang berbasis Web. Namun demikian SIPP yang berbasis Web masih terdapat kekuarangan sehingga diperlukan penyempurnaan dalam upaya mendukung kesempurnaan SIPP dalam aplikasinya, karena masih terdapatnya item - item azas berperkara sederhana, cepat, biaya ringan yang belum terakses dalam aplikasi SIPP, karena sifat dari aplikasi SIPP masih sangat global. Dan sifat Globalnya SIPP, masing masing item harus dilakukan sesuai dengan tahapan berperkara , dan tidak bisa dilakukan secara loncat - loncat yang tanpa melaui tahapan yang sesuai dengan praktek hukum acara.

Setiap User dituntut memahami secara detail aplikasi SIPP yang berbasis Web. sehingga dalam aplikasinya tidak terjadi kesalahan yang berakibat fatal pada penanganan perkara

Pelaku yang terlibat dalam Aplikasi SIPP adalah admin dan user. Secara lengkap kebutuhan Aplikasi SIPP dapat dijelaskan sebagai berikut :

1. Admin dapat memasang, menghapus, dan mengganti semua konten melalui kode program.

2. Admin dapat menginput laporan / data yang diterima;

3. User dapat melihat atau mencari data yang telah dimasukkan oleh Admin.

4. Pada kebutuhan non-fungsional, aplikasi SIPP tidak pernah gagal dalam menginput dan menampilkan seluruh data yang telah dimasukkan oleh User.

\subsection{Pengertian PHP (Hypertext Preprocessor)}

PHP adalah singkatan dari "PHP: Hypertext Prepocessor", yaitu bahasa pemrograman yang digunakan secara luas untuk penanganan pembuatan dan pengembangan sebuah situs web dan bisa digunakan bersamaan dengan HTML. PHP diciptakan oleh Rasmus Lerdorf pertama kali tahun 1994. Pada awalnya PHP adalah singkatan dari "Personal Home Page Tools". 
Selanjutnya diganti menjadi FI ("Forms Interpreter"). Sejak versi 3.0, nama bahasa ini diubah menjadi "PHP: Hypertext Prepocessor" dengan singkatannya "PHP". PHP versi terbaru adalah versi ke-5.

PHP juga banyak diaplikasikan untuk pembuatan program-program seperti sistem informasi penelusuran Perkara ( SIPP) yang di buat oleh Mahkamah Agung Republik Indonesia, yang diterapkan di seluruh Pengadilan di Indonesia.

\subsection{SQL Server}

Microsoft MySQL adalah sebuah perangkat lunak system manajemen basis data SQL (DBMS) yang multithread, dan multi-user. MySQL adalah implementasi dari system manajemen basisdata relasional (RDBMS). MySQL dibuah oleh TcX dan telah dipercaya mengelola system dengan 40 buah database berisi 10.000 tabel dan 500 di antaranya memiliki 7 juta baris.

Relational DatabaseManagement System (RDBMS) yang didistribusikan secara gratis dibawah lisensi GPL (General Public License). Dimana setiap orang bebas untuk menggunakan MySQL, namun tidak boleh dijadikan produk turunan yang bersifat komersial. MySQL sebenarnya merupakan turunan salah satu konsep utama dalam database sejak lama, yaitu SQL (Structured Query Language). SQL adalah sebuah konsep pengoperasian database, terutama untuk pemilihan atau seleksi dan pemasukan data, yang memungkinkan pengoperasian data dikerjakan dengan mudah secara otomatis. Keandalan suatu sistem database (DBMS) dapat diketahui dari cara kerja optimizer-nya dalam melakukan proses perintah-perintah SQL, yang dibuat oleh user maupun program-program aplikasinya. Sebagai database server, MySQL dapat dikatakan lebih unggul dibandingkan database server lainnya dalam query data. Hal ini terbukti untuk query yang dilakukan oleh single user, kecepatan query MySQL bisa sepuluh kali lebih cepat dari PostgreSQL dan lima kali lebih cepat dibandingkan Interbase.

MySQL memiliki beberapa keistimewaan, antara lain :

1. Portabilitas. MySQL dapat berjalan stabil pada berbagai sistem operasi seperti Windows, Linux, FreeBSD, Mac Os X Server, Solaris, Amiga, dan masih banyak lagi.

2. Open Source.MySQL didistribusikan secara open source, dibawah lisensi GPL sehingga dapat digunakan secara cuma-cuma.

3. "Multiuser". MySQL dapat digunakan oleh beberapa user dalam waktu yang bersamaan tanpa mengalami masalah atau konflik.
4. "Performance tuninge. MySQL memiliki kecepatan yang menakjubkan dalam menangani query sederhana, dengan kata lain dapat memproses lebih banyak SQL per satuan waktu.

5. Jenis Kolom. MySQL memiliki tipe kolom yang sangat kompleks, seperti signed / unsigned integer, float, double, char, text, date, timestamp, dan lain-lain.

6. Perintah dan Fungsi. MySQL memiliki operator dan fungsi secara penuh yang mendukung perintah Select dan Wheredalam perintah (query).

7. Keamanan. MySQL memiliki beberapa lapisan sekuritas seperti level subnetmask, nama host, dan izin akses user dengan sistem perizinan yang mendetail serta sandi terenkripsi.

8. Skalabilitas dan Pembatasan. MySQL mampu menangani basis data dalam skala besar, dengan jumlah rekaman (records) lebih dari 50 juta dan 60 ribu tabel serta 5 milyar baris. Selain itu batas indeks yang dapat ditampung mencapai 32 indeks pada tiap tabelnya.

9. Konektivitas. MySQL dapat melakukan koneksi dengan klien menggunakan protokol TCP/IP, Unix soket (UNIX), atau Named Pipes (NT).

10. Lokalisasi. MySQL dapat mendeteksi pesan kesalahan pada klien dengan menggunakan lebih dari dua puluh bahasa. Meski pun demikian, bahasa Indonesia belum termasuk di dalamnya.

11. Antar Muka. MySQL memiliki interface (antar muka) terhadap berbagai aplikasi dan bahasa pemrograman dengan menggunakan fungsi API (Application Programming Interface).

12. Klien dan Peralatan. MySQL dilengkapi denganberbagai peralatan (tool)yang dapat digunakan untuk administrasi basis data, dan pada setiap peralatan yang ada disertakan petunjuk online.

13. Struktur tabel. MySQL memiliki struktur tabel yang lebih fleksibel dalam menangani ALTER TABLE, dibandingkan basis data lainnya semacam PostgreSQL ataupun Oracle.

\section{METODE PENELITIAN}

\subsection{Analisis Sistem}

\subsubsection{Manajemen Perkara}

Manajemen perkara adalah satu dari lima kelompok kerja reformasi birokrasi Mahkamah Agung Republik Indonesia. Oleh Badan Peradilan Agama (Badilag) yang merupakan unit eselon 1 di lingkungan Mahkamah Agung,kelompok kerja manajemen perkara tersebut dijabarkan ke dalam 
beberapa program, yaitu program penyelesaian perkara dan program implementasi SIADPA (Sistem Informasi Administrasi Perkara Pengadilan Agama). Program penyelesaian perkara difokuskan pada penanganan perkara secara cepat dan tepat. Sehingga, produk pengadilan berupa putusan atau penetapan bisa dihasilkan kurang dari 6 bulan sejak perkara didaftarkan di pengadilan agama. Sedangkan program implementasi SIADPA dititik beratkan pada penggunaan aplikasi berbasis teknologi informasi untuk menunjang sekaligus memperlancar perjalanan berkas perkara mulai dari pendaftaran sampai dengan pengarsipan. SIADPA adalah aplikasi yang berfungsi sebagai input awal sampai akhir proses perkara, keuangan perkara, register (pencatatan) perkara, dan pelaporan perkara tingkat pertama. Di awal penggunaannya sekitar tahun 2007, SIADPA masih dipandang sebelah mata. Terbukti dengan belum dipakainya aplikasi tersebut secara menyeluruh oleh beberapa pengadilan agama. Maka dari itu, di tahun 2010 melalui buku Pedoman Pelaksanaan Tugas dan Administrasi Peradilan Agama (Buku II), Badan Peradilan Agama menghimbau kepada seluruh Pengadilan Agama di Indonesia untuk memanfaatkan aplikasi SIADPA dalam rangka mendukung Pola Bindalmin (Pola Pembinaan dan Pengendalian Administrasi Kepaniteraan) dan peningkatan kinerja pengadilan serta pelayanan peradilan. Sehingga di tahun yang sama, SIADPA berubah nama menjadi SIADPA Plus yang merupakan pengembangan dari aplikasi SIADPA yang sudah diselaraskan dengan Pola Bindalmin sekaligus makin mudah digunakan.

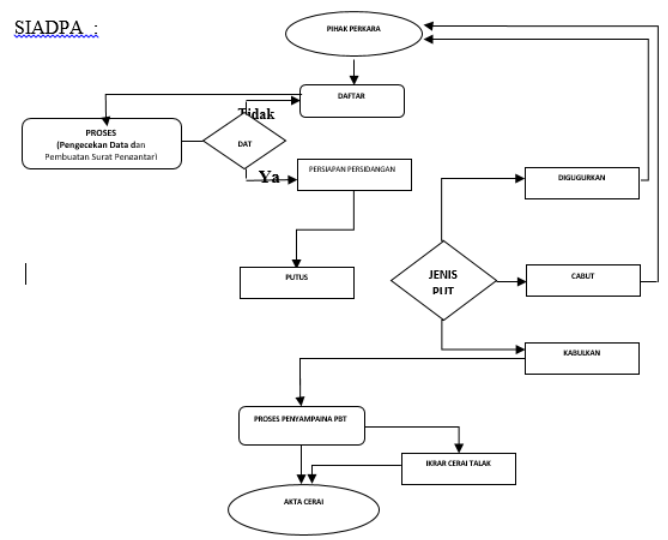

Gambar 3.1 Diagram manajemen perkara

\subsubsection{Manajemen Perkara}

Sistem Informasi Penelusuran Perkara (SIPP) adalah aplikasi teknologi berbasis web dalam memberikan informasi perkara kepada masyarakat. Selain itu SIPP juga bisa digunakan oleh pimpinan untuk memonitor kinerja hakim di daerah. SIPP dibangun sebagai media kerja yang baik dan efektif bagi internal pengadilan, tertib administrasi, efektif dan efesien, monitoring dan pengawasan dan yang terpenting adalah media yang memudahkan masyarakat pencari informasi perkara untuk mengupdate informasi perkaranya dengan mudah, cepat dan berbiaya murah. Sehingga dengan format SIPP versi 3.2.0, masyarakat dapat mengontrol pelaksanaan proses pengadilan melalui Webside, dimana terdapat fitur - fitur baru yaitu penambahan fungsi template, delegasi on line, dan integrasi dengan Sistem Informasi Administrasi Perkara (SIAP) Mahkamah Agung dan Direktori Putusan.

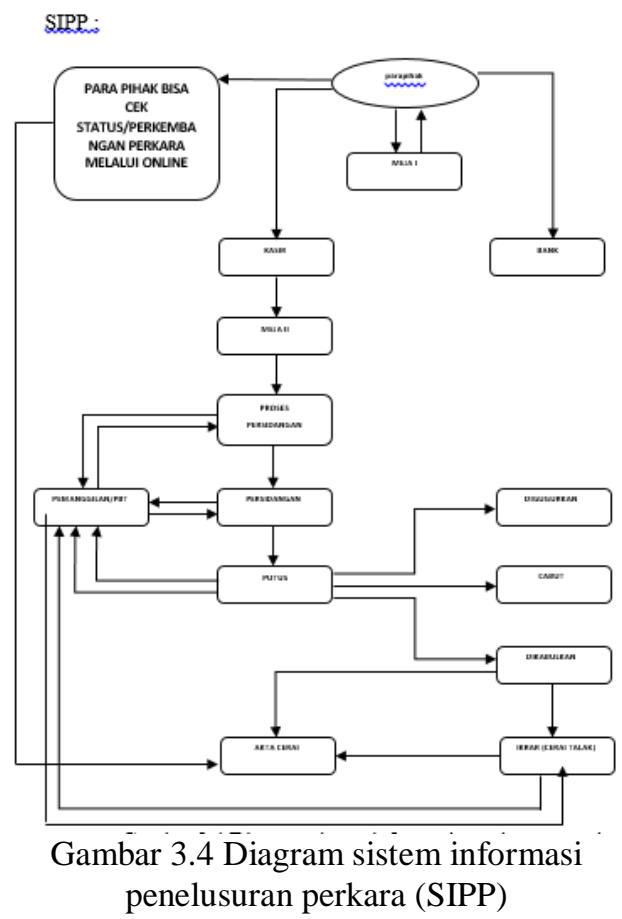

\subsection{Desain Arsitektur Sistem}

Sistem ini dibuat dengan menggunakan bahasa pemograman php dan database Mysql. Database SIPP digunakan untuk mengambil data para pihak yang mengajukan pengambilan akta cerai sehingga operator tidak perlu mengetik ulang biodata yang sudah ada di database SIPP, sistem ini dibuat karena kebutuhan yang ada dilapangan dan bahasa pemograman PHP sangat aman untuk digunkan di server CENTOS yang ada di pengadilan agama lumajang. 


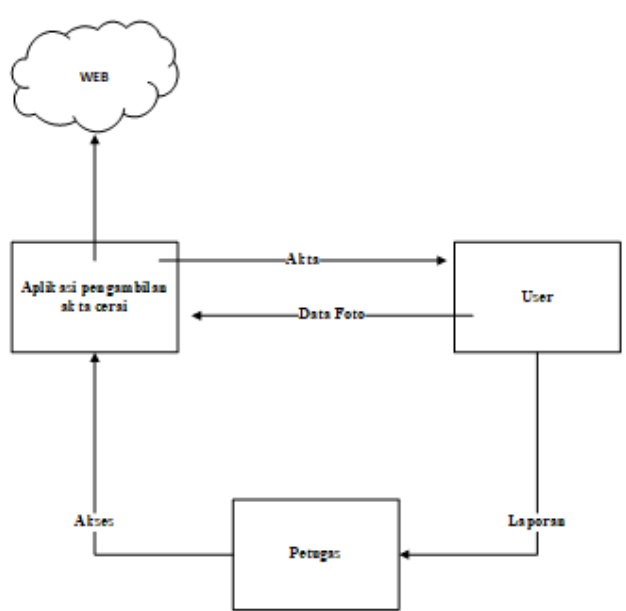

Gambar 3.2 Arsitektur database sipp

Aplikasi SIPP adalah sitem informasi penelusuran perkara yang dilunching pada tahun 2016 oleh Mahkamahagung, di versi yang pertama SIPP banyak kekurangan semakin dari sana SIPP terus melakukan update penyempurnaan untuk memajukan 4 peradilan di Indoensia, namun peradilan di bawah Mahkamahagung tidak kalah untuk berinovasi untuk membantu menyempurnakan aplikasi SIPP dengan ketentuan tidak diperbolehkan untuk mengurangi atau menambah database yang ada berserta coding yang ada di SIPP namun boleh menampilkan/load view database di SIPP di aplikasi lain.

Contohnya aplikasi PTSP yang sebagian besar mengabil dari database SIPP dan menambhkan fitur resk resiko jadi memperkecil resiko yang terjadi pada Pengadilan Agama Lumajang yang kebanyakan arsip masih disimpan manual dan resiko rusak atau hilang sangat besar.

Petugas dalam hal Akata cerai/Meja III melakukan verifikasi data yang ada di palikasi SIPP dan menunggu Jurusita menyampaikan PBT lalu petugas tinggal menyetak Akta cerai jika telah BHT 14 hari setelah disampaikan oleh jurusita/penyampaian PBT.

Petugas di SIPP hanya menyetak Akta Cerai dan menginputkan data Akta cerai, jika ada para pihak mau mengambil Akta Cerai maka petugas tinggal menyerahkan kepada para pihak dan sebelum itu petugas melakuka foto cupcuter kepada pihak yang mengambil akta cerai di aplikasi PTSP dan melakukan penginputan tanggal pengambilan data para pihak yang mengambil otomasi tersimpan di database.

\section{HASIL DAN PEMBAHASAN}

\subsection{Implementasi}

Implementasi system adalah Tahap penerapan sistem yang akan dilakukan jika sistem disetujui termasuk program yang telah dibuat pada tahap perancangan sistem agar siap untuk dioperasikan. Implementasi Sistem Informasi OrderCenterberbasis intranetini dilakukan menggunakan bahasa pemrograman PHP dengan basis data yang digunakan adalah MySQL. Aplikasi PHP tersebut dapat dijalankan pada berbagai platformsistem operasi dan perangkat keras, tetapi implementasi dan pengujian sepenuhnya hanya dilakukan pada perangkat Laptop dengan sistem operasi Microsoft Windows 7 diatasnya. Yang diperlukan selain perangkat laptop juga software seperti xampp.

XAMPP adalah yang merupakan singkatan dari Apache, MySQL, PHP dan Perl sedangkan huruf "X" dimaksudkan sebagai suatu software yang dapat dijalankan di empat OS utama seperti Windows, Mac OS, Linux dan Solaris. Istilah ini seringkali disebut dengan cross platform (software multi OS). Sesuai dengan namanya software yang satu ini merupakan gabungan dari beberapa software dengan fungsi yang sama yakni menunjang para pembuat web yang menginginkan adanya web server sendiri di PC atau laptopnya. Software ini juga berlisensi GNU dan dapat didownload secara gratis di internet mengingat peran vital yang dimilikinya terutama bagi pembuat web pemula.

\subsubsection{Halaman Log In}

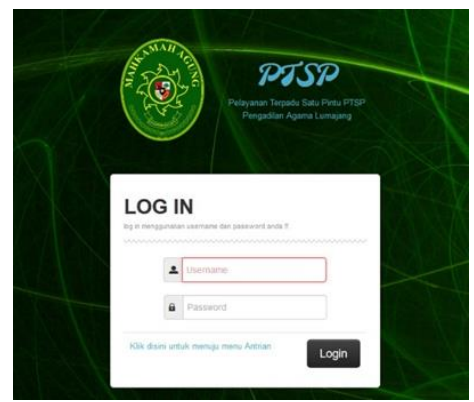

Gambar 4.1.1 Halaman log in

Pada gambar di atas adalah halaman log in untuk masing-masing user yang telah di daftarkan pada aplikasi ini, pada halaman ini user di haruskan mengetahui user dan password yang telah di buat oleh admin.

\subsubsection{Halaman Utama}

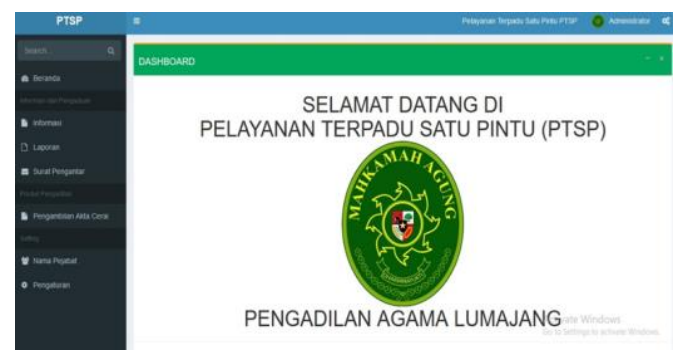

Gambar 4.1.2 Halaman utama 
Pada gambar di atas adalah halam utama setelah kita berhasil log in ke masing-masing user, ini halaman full control yang dimiliki oleh admin berbeda dengan halaman utama dengan user bukan admin atau tidak full control.

\subsubsection{Halaman Informasi}

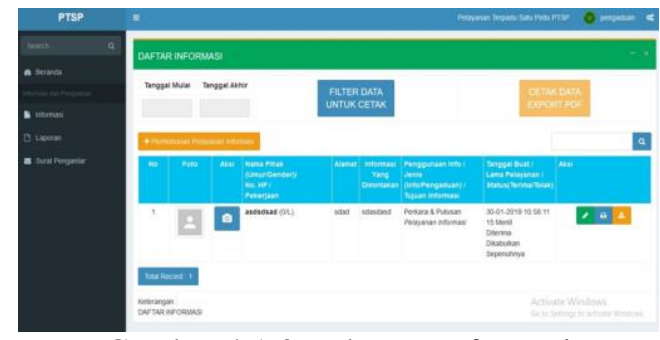

Gambar 4.1.3 Halaman Informasi

Pada gambar di atas adalah informasi ini ada 3 menu yaitu infromasi, laporan, surat pengantar

\subsubsection{Halaman menu Pengambilan Akta Cerai}

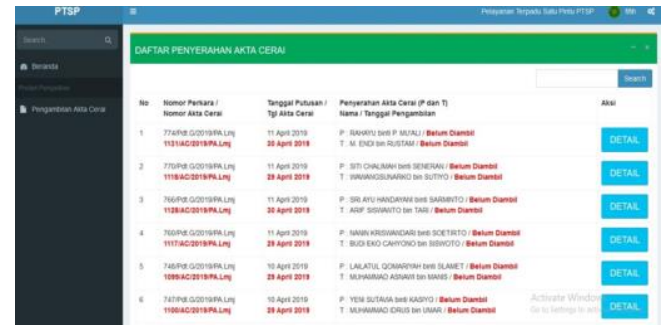

Gambar 4.1.4 Halaman menu Pengambilan Akta Cerai

Pada gambar di atas adalah menu pengambilan akta cerai dimana petugas akta cerai akan secara otomatis terlihat data perkara yang belum mengambil akta cerai disana terlihat data yang belum dan yang sudah mengambil akta cerai, data ini akan tampil secara otomatis dari aplikasi SIPP.

\subsection{Pengujian Sistem}

Implementasi adalah bagian dari Analisa Sistem Baru yang telah dijelaskan pada bab sebelumnya Analisa dan Perancangan. Dalam hal ini implementasi merupakan tahap dimana sistem siap dioperasikan pada keadaaan yang sebenarnya, sehingga akan diketahui apakah sistem yang dibuat benar-benar dapat menghasilkan tujuan yang ingin dicapai. Sistem ini dibangun dengan berbasis web dengan menggunakan bahasa pemrograman PHP.

\subsubsection{Pengujian Aplikasi}

Pada Pengujian Aplikasi ini dicoba dijalankan dengan perangkat keras dan menggunakan perangkat lunak yang di jelaskan pada bab 4.1 dan semua berjalan dengan lancer dan semua fitur tercapai apa yang diharapkan.

\subsubsection{Pengujian User}

Pengujian User dilakukan untuk mengetahui apakah system berjalan dengan baik atau tidak. Pengujian dilakukan terhadap 5 orang Petugas, hasil dari pertanyaan terhadap responden dapat dilihat pada table dibawah ini

\begin{tabular}{|l|l|l|l|l|}
\hline \multirow{2}{*}{ No } & \multicolumn{2}{|c|}{ Pertanyaan } & \multicolumn{3}{|c|}{ Nilai } \\
\cline { 3 - 5 } & & Baik & $\begin{array}{c}\text { Cuku } \\
\mathrm{p}\end{array}$ & Kurang \\
\hline 1. & Bagaimana desain dari Menu Log in? & $80 \%$ & $10 \%$ & $10 \%$ \\
\hline 2. & Bagaimana fungsi Fitur Aplikasi PTSP? & $78 \%$ & $12 \%$ & $10 \%$ \\
\hline 3. & Bagaiman dengan Fitur setiap User? & $68 \%$ & $22 \%$ & $10 \%$ \\
\hline 4. & $\begin{array}{l}\text { Apakah Aplikasi ini mempermudah } \\
\text { kerja petugas dilapangan? }\end{array}$ & $75 \%$ & $15 \%$ & $10 \%$ \\
\hline 5. & Apakah aplikasi berjalan dengan baik? & $78 \%$ & $10 \%$ & $12 \%$ \\
\hline
\end{tabular}

\subsubsection{Pengujian Admin}

Pengujian admin dilakukan untuk bias membantu kepada petugas yang melaksanakan pekerjaan serta mengontrol data yang masuk kedalam aplikasi.

\begin{tabular}{|l|l|l|l|l|}
\hline \multirow{2}{*}{ No } & \multicolumn{1}{|c|}{ Pertanyaan } & \multicolumn{3}{c|}{ Nilai } \\
\cline { 3 - 5 } & & Baik & $\begin{array}{c}\text { Cuku } \\
\mathrm{p}\end{array}$ & Kurang \\
\hline 1. & $\begin{array}{l}\text { Apakah admin dalam aplikasi ini full } \\
\text { control? }\end{array}$ & $90 \%$ & $5 \%$ & $5 \%$ \\
\hline 2. & $\begin{array}{l}\text { Bagaimana dengan data yang massuk } \\
\text { apakah sudah benar? }\end{array}$ & $99 \%$ & $1 \%$ & $0 \%$ \\
\hline 3. & $\begin{array}{l}\text { Bagaimana dengan keamanan data yang } \\
\text { ada di aplikasi }\end{array}$ & $99 \%$ & $1 \%$ & $0 \%$ \\
\hline 4. & $\begin{array}{l}\text { Bagaimana admin dalam mengontrol } \\
\text { data yang di input petugas sudah puas? }\end{array}$ & $80 \%$ & $10 \%$ & $10 \%$ \\
\hline 5. & Apakah aplikasi ini sudah tepat guna? & $80 \%$ & $10 \%$ & $10 \%$ \\
\hline
\end{tabular}

\section{KESIMPULAN DAN SARAN}

5.1 Kesimpulan

1. Cara - cara untuk pengambilan akta cerai adalah :

a. Para pihak yang akan mengambil akta cerai menyerahkan nomor perkaranya,

b. Para Pihak memperlihatkan KTP Asli dan menyerahkan fotokopinya,

c. Para pihak membayar penerimaan negara bukan pajak (PNBP),

2. Adapun untuk meminimalisir kesalahan pengambilan akta cerai adalah:

a. Diciptakannya sistim aplikasi pengambilan akta cerai,

b. Penerapan sistim aplikasi pengambilan Akta Cerai, 


\subsection{Saran}

Adapun saran yang dapat diberikan setelah pengujian adalah sebagai berikut :

1. Hendaknya user menguasai sistim aplikasi pengambilan akta cerai untuk memudahkan dan mempercepat pengambilan Akta Cerai.

2. Perlu inovasi lebih lanjut penyempurnaan aplikasi pengambilan akta cerai sehingga tidak terjadi komplain para pihak yang mengambil akta cerai.

\section{DAFTAR PUSTAKA}

[1] Hartono, D.U. and Mulyanto, E., 2010. Electronic Government Pemberdayaan Pemerintahan dan Potensi Desa Berbasis Web. Jurnal Teknologi Informasi, 6(1), pp.9-21.
[2] Tsabit, A., Ramdhani, M.A. and Cahyana, R., 2012. Pengembangan Ganesha Digital Library untuk Membuat Situs Jurnal. Jurnal Algoritma, 9(01).

[3] Zuliarso, E. and Mustofa, K., 2009. Crawling Web berdasarkan Ontology. Dinamik, 14(2).

[4] As' ali, S., 2018. Kewenangan Penerbitan Akta Perceraian Bagi yang Beragama Islam. Mimbar Keadilan.

[5] Pramono, R., Santoso, B. and Widhiyanti, H.N., 2018. Konsekuensi Yuridis Dari Ketiadaan Akta Cerai Akibat Perkawinan Kedua Atau Lebih Terhadap Pembuktian Status Harta Bawaan. Jurnal Selat, 6(1), pp.125-144.

[6] Sinaga, A., 2019. Kebijakan Hukum Pidana Pada Praktik Pungutan Liar Dalam Penerbitan Akta Perkawinan Tanpa Ada Akta Perceraian. 